https://doi.org/10.31713/m1004

\title{
ALTERNATIVE DIRECTIONS OF PEAT USE
}

\section{Moshynskyi V.S.}

National University of Water and Environmental Engineering (NUWEE), Rector, Professor, Doctor of Sciences (Agricultural), Professor, Department of Land, Cadaster, Land Monitoring and Geoinformatics, Ukraine

\section{Mohamed Tafsir Diallo}

Polytechnic Institute of Gamal Abdel Nasser University of Conakry, Managing Director, Republic of Guinea

\section{VasylchukO.Yu.}

National University of Water and Environmental Engineering (NUWEE), Associate Professor, Department of Mining and Mining, Ukraine

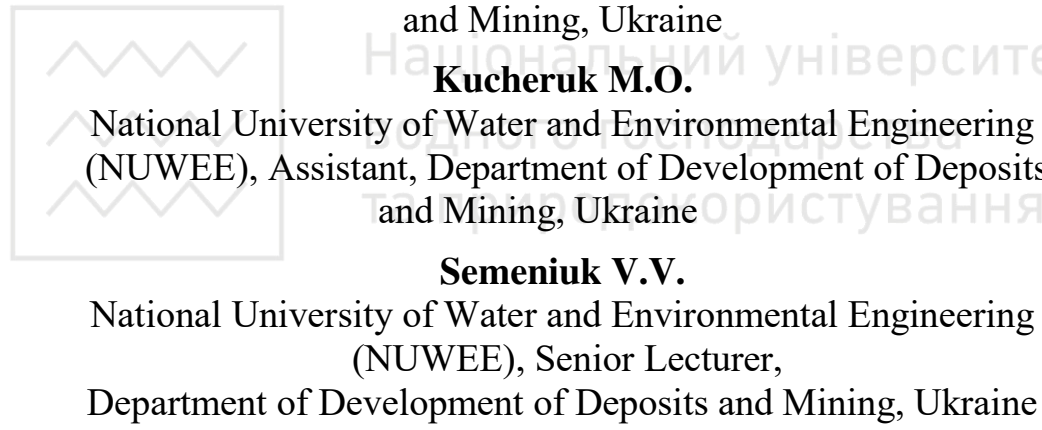

\section{Summary}

Peat extraction and processing in the world is a highly profitable and promising type of business. This section describes and discloses the essence of alternative uses of peat. The physical and chemical properties of peat are given. Emphasis is placed directly on the use of peat in the world and in Ukraine.

\section{Introduction}

Peat is a rock of plant origin, formed over thousands of years from under composed plant residues (grasses, mosses and wood), which due to high humidity and poor air access partially (about 50\%) mineralized.

Peat deposits are common in all climatic zones and are in many countries. The most intensive accumulation of peat is characteristic of the northern hemisphere - Northern Europe, Western Siberia and 
North America. The total area of peat deposits in the world is estimated at 176 million hectares. The modern wetland of the land is $4.5 \%$ of its total area, and the average annual growth of wetlands on the globe for the last 10 thousand years was 658 square kilometers. The largest reserves of peat are concentrated in the CIS countries (40.0\%), Indonesia (13.6\%), Finland (7.0\%), Canada (7.0\%), USA $(7.0 \%)$, China $(5,4 \%)$ and Sweden $(2.4 \%)$. World peat resources are estimated at 2 trillion tons, of which 770 billion tons are in the CIS, 510 - in Canada. Annual world production of peat is 26-28 million tons. Its largest volume is accounted for by Finland, Ireland (5.5 million tons each) and Germany - 4 million tons. On average, from one to two million tons per year are produced in the Russian Federation, Belarus, Canada and Sweden. In Scandinavia, a large proportion of peat is used as energy raw materials.

In Ukraine, most swamps are peat lands. The latter term is often used for drained marshes; sometimes under peat land understand the peat bog, especially when developing it. In the marshes of Ukraine lowland peat deposits prevail, in the Western Polissia and Carpathians mixed transitional types occur. Top and mixed top types of deposits are known in Western and Central Polissia, in the Carpathians. The most widespread peat deposits are in Rivne, Volyn, Chernihiv, Zhitomyr, Kyiv, Lviv regions. Tariffs of Rivne and Volyn regions reach $6.5 \%$, while in Ternopil, Khmelnitsky, Vinnitsa, Cherkasy, Poltava, Sumy and Kharkiv regions it does not exceed $1.9 \%$ of the whole territory. Even less common are peat deposits in Mykolaiv, Zaporizhia, Dnipropetrovsk, Transcarpathian, Ivano-Frankivsk regions, where the degree of peat land does not exceed $0.1 \%$ [1].

The Ukrtorf concern produces up to 600,000 tons of peat annually, the vast majority of which (62\%) is converted to fuel briquettes - a fairly efficient solid fuel with a lower combustion heat of about $15 \mathrm{MJ} / \mathrm{kg}$, humidity up to $20 \%$ and ash content up to $23 \%$.[1]

The set of properties of peat differs sharply from other minerals. The chemical composition and properties of peat vary in a wide range depending on the type, species, degree of decomposition, acidity, ash content, etc. [2], so the directions of its use are extremely diverse.

The substance of peat contains partially decomposed plant residues, their decomposition products in the form of dark amorphous humic substance and a mineral part. In the natural state, 
peat contains $85-95 \%$ water, and in the solid part - up to $50 \%$ of mineral compounds. The organic matter of peat contains $48-65 \%$ carbon, $4.7-7.3 \%$ hydrogen, $24.7-45.2 \%$ oxygen, $0.2-1.2 \%$ sulfur and $0.5-4.0 \%$ nitrogen [3]. Humus gives peat a dark color.

The elemental composition reflects the nature of the original plant material and the nature of its change during peat formation, as well as determines the botanical composition of peat, and nutritional conditions and the type of peat-forming plants determine the type of peat. Peat formed from plants of mainly atmospheric (oligotrophic) nutrition with a content of plant residues not less than $95 \%$ is called upland, and from plants of rich (eutrophic) nutrition, with a content of such plant residues not less than $95 \%$, is called lowland. Peat, in which $10-90 \%$ of plant remains of one type and the rest - another, as well as there are remains of sphagnum mosses of mesotrophic type, is called transitional. Each type consists of subtypes: forest subtypes, forest-swamp and swamp, and the subtypes are divided into groups: tree, tree-grass, tree-moss, grass, grass-moss and moss. There are 20 species of lowland, 8 transitional and 12 upper peats. The level of biochemical decomposition of peat-forming plants is characterized by the degree of decomposition, which shows the proportion of unstructured peat that has lost the cellular structure of the substance. The degree of decomposition varies from 1 to $75 \%$.

Depending on the geobotanical characteristics, the composition of peat changes significantly. During the transition from upper to lower peat, the content of nitrogen, humic acids and fulvic acids increases, while the number of components characteristic of plants (bitumen, water-soluble, hydrolyzed substances and cellulose) decreases by 1.5-3.0 times. In the component composition of the organic mass, the content of water-soluble substances is $1-5 \%$, bitumen $2-10 \%$, easily hydrolyzing compounds $20-40 \%$, cellulose $4-10 \%$, and humic acids $15-50 \%$ lignin $5-20 \%$.

Peat is characterized by high moisture resistance in natural occurrence (88-96\%), porosity up to $96-97 \%$ and a high coefficient of compressibility during compression tests [3]. The texture of peat is homogeneous, sometimes layered; the structure is usually fibrous or plastic. The color is yellow or brown to black. Weakly decomposed peat in the dry state has a low density (up to $0.3 \mathrm{~g} /$ 
$\mathrm{cm} 3$ ), low thermal conductivity and high gas absorption capacity. Peat of high dispersion (after mechanical processing) forms dense pieces during drying with high mechanical strength and calorific value of $2650-3120 \mathrm{kcal} / \mathrm{kg}$ (at $40 \%$ humidity).

An important advantage of peat is its peculiar combustion. After all, peat fibers contain oxygen, so peat is able to burn without additional oxygen supply.

Peat is considered the first stage in the formation of fossil coal. It is used as fuel, building material, raw materials for the chemical industry, soil remediation agent, moisture absorber.

For greater clarity of the directions of use of peat in Ukraine and the world, this paper presents two schemes of integrated peat use in Fig. 1. and Fig 2.

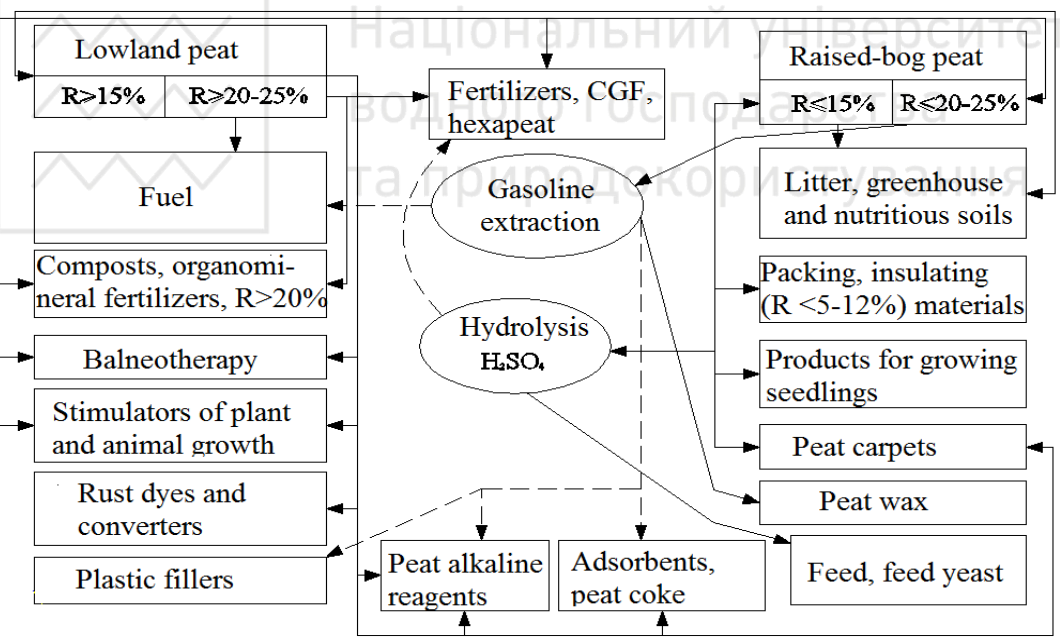

Fig. 1. Scheme of complex use of peat in Ukraine and the world The solid line shows the areas of peat use, the dashed line shows the waste of the respective production 


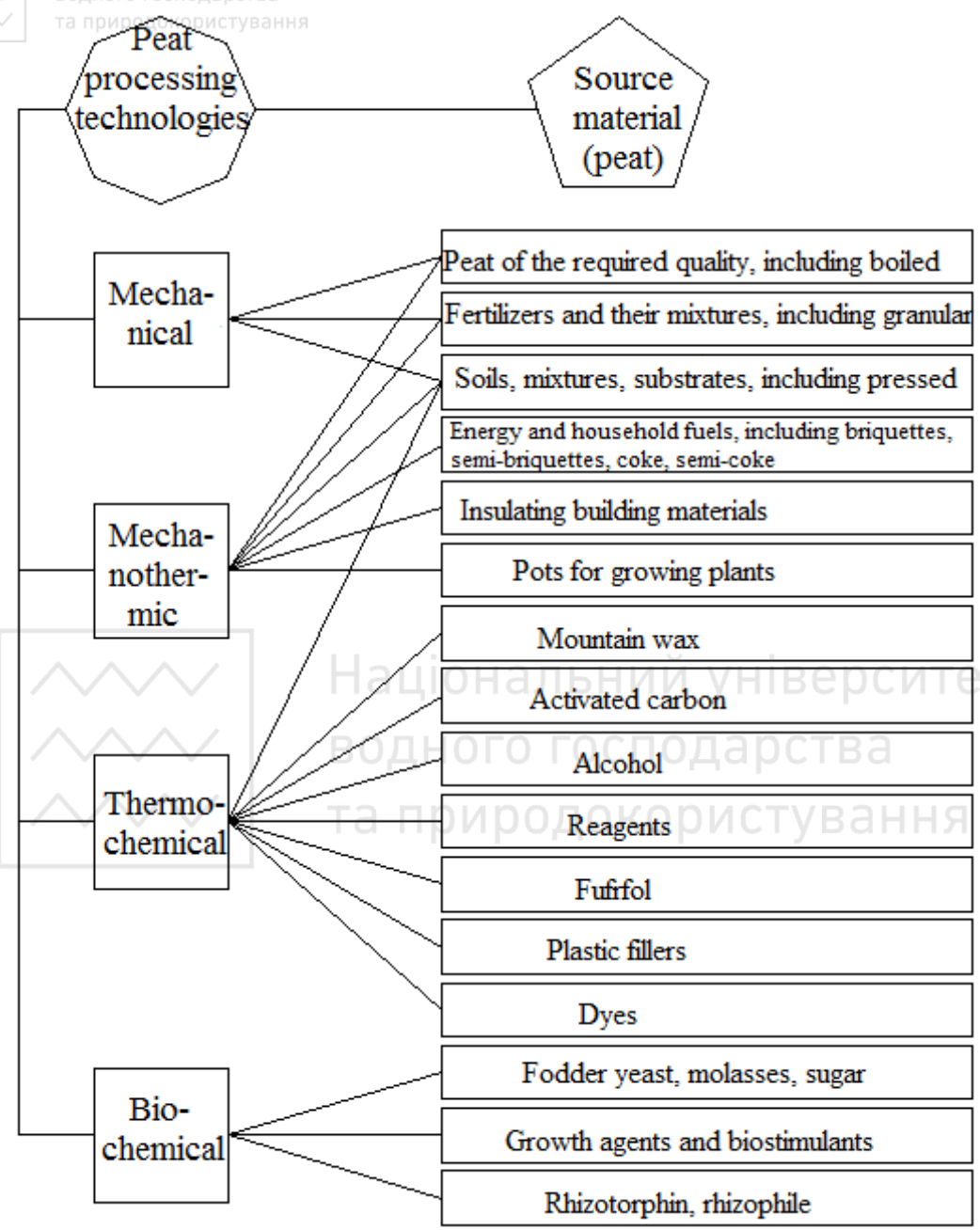

Fig. 2. Block diagram of peat processing technologies and its main products

\section{The use of peat as fuel}

Currently, about 500 peat deposits are being developed in Ukraine. Approximately $81 \%$ of peat extracted in Ukraine is used as fuel and $19 \%$ as fertilizer. 
Despite the discovery of new energy sources, the use of peat as a fuel continues and will increase for energy and utilities in order to improve the fuel problems of today.

The use of peat as a fuel during its combustion is more environmentally friendly than coal, fuel oil and shale [4].

The main consumers of peat are agriculture and industrial and energy complex [5]. Previously, peat was commonly used as a household fuel, but over time it began to be widely used in industry and energy in the form of milling crumb, briquettes and pellets.

In small volumes (about 15 thousand tons) Ukraine exports peat products (mainly as fuel), and imports some varieties of peat (about 1700 tons).

Given the limited reserves of reised-bogpeat in Ukraine, as well as the situation on the fuel market in the country, we can agree with the statement that the main use of peat in modern conditions - the production of peat fuel (peat briquettes and lump peat) for public consumption [2].

The use of peat as a fuel is due to its composition: high carbon content, low sulfur content, harmful non-combustible residues and impurities. In fact, it is young coal. The main disadvantages of this type of fuel are: lower than coal energy value (heat of combustion) and the difficulty of combustion due to high moisture content (up to $65 \%$ ).However, along with this peat has a number of advantages:

- low production costs;

- ecological purity of combustion (small percentage of sulfur);

- complete combustion (small residue and non-toxicity of ash);

- new combustion technologies that have appeared.

All this makes peat a promising local source of heat and electricity: cheaper than using coal and liquid fuels and more environmentally friendly.

The feasibility of introducing small thermal power plants on peat requires a more detailed study, based on the experience of Finland, where about $15 \%$ of electricity is produced by burning it [2].

\section{The use of peat in agriculture}

Agricultural direction is one of the main areas where peat is actively used. This is a great environment for growing all plants. Peat is used in the manufacture of various fertilizers, as well as substrates that are indispensable for plants grown in greenhouses. Peat is also 
used to make lawn mixtures. Peat is added to the soil to improve its properties, it also has bactericidal and gas-absorbing properties, which heals the soil, destroys a certain amount of nitrates, and stimulates vegetation growth. Peat is not only a good basis for the production of various fertilizers, it is an ameliorant in the literal sense of the term, as it allows not only to introduce the necessary nutrients into the soil, but also to improve a number of properties of the fertile soil layer [6].

Peat contains humic acids, which stimulate the growth and development of plants, and amino acids needed to convert certain components of food into a form accessible to plants.

Peat has bactericidal and gas-absorbing properties, which are equally necessary for all types of soils. Peat heals the soil, reduces the content of nitrates in the product by 1.5-2 times, prevents the accumulation in plants of heavy metals and other harmful substances, weakens the effects of pesticides that enter the soil. Humus, which is formed in the soil during prolonged application of peat, prevents the leaching of easily soluble fertilizers.

To grow seedlings in greenhouses make special peat-humus pots, which is consist of a mixture of peat and rotted manure.

Advantages of peat and rationality of its use:

- Peat itself does not nourish plants, but helps them better absorb other fertilizers.

- The soil into which the peat has been applied becomes more structural, that is, one that consists of lumps and pores likes a sponge. This soil retains moisture, air and nutrients well.

- It makes sense to use peat only on poor, infertile or depleted soils.

- Peat is considered a natural antiseptic and inhibits the development of harmful fungi and bacteria.

- Peat (horse) can regulate the acidity of the soil, adjusting it to the needs of plants.

Peat is used as a litter for livestock and birds, because it retains and keeps heat, absorbs moisture and is very soft in texture. The ability of dry peat to absorb moisture and odors allows it to be used as bedding for livestock. One kilogram of light peat holds up to 20 liters of water. The resulting mixture can be composted without finishing. Another advantage of using peat for bedding is its 
bactericidal properties: peat prevents many diseases in animals. Peat litter is more profitable than straw or sawdust: 1 ton of such litter later gives 5 tons of high-quality organic fertilizer.

Peat also purifies water from excess acidity, so it has found its application in the manufacture of filters for aquariums.

A large share of peat resources is used in agriculture. In countries such as Russia, Latvia, Belarus, Ukraine and some others, there are plants that produce mineral fertilizers based on peat. Peat soils used for growing vegetables, horticultural crops and rice crops have also been widely used [5].

The trend of peat production, namely, the direction, volume and pace, are determined not only by the resources of peat, but also, to a large extent, the needs for relevant products. Thus, in countries with cold climates, such as Russia, the Baltic countries, sphagnum peat is widely used as bedding, greenhouse and nutritious soils, as well as for the manufacture of micro greenhouses and micro districts.

In many countries of the world peat in the form of crumbs is used for packing of perishable products, vegetables and fruit at long transportations. In some countries, it is used to treat wastewater, land surface from petroleum products and as a raw material for the chemical and energy chemical industries [2].

\section{Peat for breeding worms}

In addition to horticulture and vegetable growing, the use of peat is gaining popularity in the cultivation of earthworms, manure, California worms and Dendroben worms for fishing.

The best food and habitat for the worm will be horse neutral peat, from which, as a result of the activity of worms, you can get compost. This environmentally friendly, natural organic fertilizer can then be used in the cultivation of vegetables, fruit trees and berry bushes.

\section{Peat for breeding snails}

A new area of application of peat is the breeding of snails. Previously, snails were kept at home in the terrarium as "pets", now their cultivation has grown to an industrial scale.

Peat with neutral acidity is used as litter in the cultivation of grape snails. Their meat can be eaten it contains a large percentage of protein. Peat is also used by mollusks as nests where they lay their eggs. Snail caviar is made from eggs. Snail caviar is a new delicacy 
that is considered more valuable and, accordingly, more expensive than black and red fish caviar.

\section{The use of peat in medicine}

In medicine, peat is used for mud treatment and drug production. For general and local applications use lowland and upper peat of the increased degree of decomposition, in the form of raw or in the form of milling peat without any special long processing. The simplicity of the method of peat treatment with its high efficiency has made this method a very valuable treatment in practical medicine [5]. The health and therapeutic properties of peat have long been known. From ancient times in Greece peat baths were used to treat joint diseases and female reproductive disorders. Currently, peatcontaining drugs are used to prevent and treat a wider range of injuries and diseases. Produce drugs for the treatment of eye diseases, burns and inflammatory processes.

Activated charcoal from peat is used to clean gases, air, medicines, food, etc.

The most valuable active ingredient in peat is unique macromolecular bonds, which are called humates (derived from the term "humus" - fertile).Among organic compounds, they occupy a special niche because they are formed by thermodynamic survivability, and not by genetic rules, as most. This explains the unique value of humates, their physiological activity and positive health effects.

The anti-infective properties of peat have been known since ancient times. Today, peat baths are widely used in health resorts in Western Europe, which use bactericidal and healing properties of peat.

\section{Peat in the chemical industry}

More than one hundred basic chemical products are obtained from peat: methyl and ethyl alcohol, combustible gases, phenol, wax, artificial wax, tar, coke, paraffin, lactic, acetic and oxalic acids, ammonia, plant growth stimulants, herbicides and much more. The fibers of the fluff, which are part of the peat, can be used in the manufacture of fabrics. Chemical products from peat are obtained by semi-coking, gasification, wet charring, and extraction. In terms of carbohydrate content and quality, peat is a raw material suitable for chemical and biochemical processing. 
Coke, gas, briquettes, activated carbon, bitumen, wax, humic acids and other products are obtained from peat by thermal processing [7].

Peat processing products are used in mechanical engineering, furniture, printing and cosmetics industries, in the production of household chemicals [8].

\section{The use of peat in construction}

Peat can be used to grow peat carpets. Peat carpets are lawn-type coverings that are formed by the interweaving of fibrous root systems and the terrestrial part of grassy plants on a peat basis [9]. With the help of peat carpets strengthen the ditches of roads landscaping. Peat carpets are used to create decorative, sports and other types of lawns. In addition to decorative and aesthetic, sod coverings are of great economic importance, especially for strengthening the earthen slopes of roads and railways, in the construction of reclamation facilities, consolidation of river banks and reservoirs.

In many countries of the world are engaged in special cultivation of turf on both mineral (grass carpets) and peat-based (peat carpets).

Nowadays, it is quite effective to create a lawn with peat carpets from perennial grasses.

Creation of a turf covering on steep slopes by a method of sowing of seeds of grasses is inefficient as a considerable part of seeds is washed away by rains. Under such conditions, to protect the slopes from water and wind erosion, it is necessary to dramatically reduce the time of soil deforestation. To do this, it is best to use peat carpets, pre-grown (30-40 days) grown on a drained peat deposit.

The best basis for the cultivation of peat carpets is horse peat of the moss group, which has a high hydrolytic $\left(\mathrm{H}_{\mathrm{g}}=101-175 \mathrm{mmol}\right.$ equivalent/100 grams of dry matter) and exchange $\mathrm{H}_{\text {exch. }}(\mathrm{pH}=2.5$ 4.7) acidity compared to ordinary soils (turf soil -1-2; podzol - 3-5 mmoll equivalent/100 grams of dry matter), which allows you to grow high quality carpets.

The technology of turf production is based on the creation of optimal conditions for the development of grasses, which form a peat turf from the roots, bases of shoots and green aboveground mass of the grass layer. 
The mixture of seeds of perennial grasses is wrapped in a thin cultivated layer of peat deposit, which provides the necessary conditions for plant development. The interweaving of plant roots with peat fibers forms a strong peat base of the carpet. The layer of peat becomes an integral part of the finished turf. The penetration of plant roots into the deposit does not occur due to the high natural acidity of the lower layers of the peat deposit.

In Greenland, the Eskimos cut bricks out of peat, build a hut and cover it with snow. This house is suitable for living even during the polar winter.

A house built using peat retains heat much longer than wood or stone. In Norway, for centuries, peat covered the roofs of houses. Grass, flowers and even small trees grow on such roofs. The peat roof is very beautiful. It is durable, has good thermal and waterproofing properties. About 4-5 years ago in Ukraine began to use the roofs of high-rise buildings for private purposes. Every year in Ukraine the number of complexes with a rooftop lounge area grows.

The difference between the operated roof and the usual one is that the first one has a small slope in the range of 2-15 degrees. This decision prevents the formation of puddles after rain or in the spring, when the snow melts. Such a roof is created from several layers of material. This allows the roof to withstand heavy loads, not to collapse under the weight of the premises, furniture, greenery and people.

The first layer must be reinforced base, then laid vapor barrier and insulation, followed by a sloping floor screed, waterproofing and protective-separating layer. Only then does the roof appear on the coating in the form of soil with peat, non-slip tiles, wood, etc. (Fig. 3). 


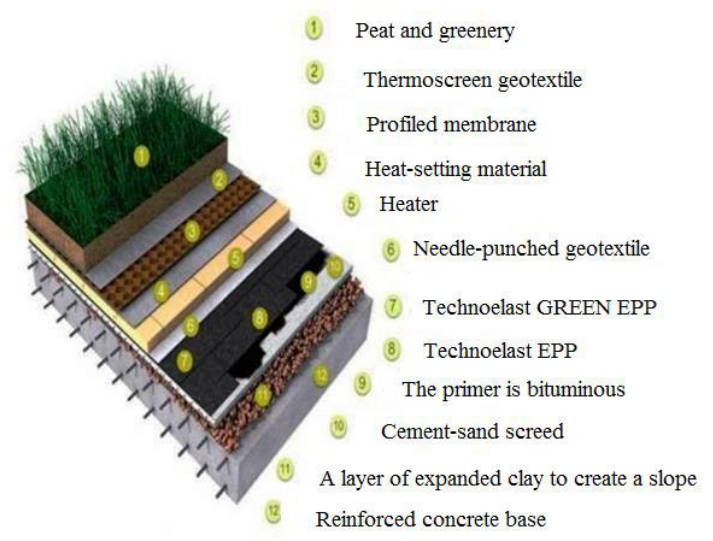

Fig. 3.The structure of the "green roof"

As the operated roof bears a significant load, in the process of its creation only durable and high-quality building materials are used. Otherwise, the roof will collapse and will not be able to withstand the constant impact of negative factors such as snow, rain, heat, etc. According to the type of roofing, the roof can be divided into 2 types for further use. Inversion - it has a layer of waterproofing located under the insulation. This option is suitable for those projects where plants are planned to be planted on the roof. As an additional layer, builders also use a drainage profiled membrane, fertile and filter layer. This promotes the full growth of flowers, shrubs and trees, and also protects the roots from the effects of changing weather. The second variety is traditional. In this operated roof, the waterproofing layer is located directly above the thermal insulation layer. This type of roof is easier to implement. It also does not require specific maintenance.

From certain types of peat, which are on the territory of Ukraine and meet certain requirements, which are given in table 1 , it is possible to receive organic fertilizers, fuel, peat litter, heat-insulating plates, fodder yeast, activated carbon, metallurgical fuel, mining wax. 
Table 1

Requirements for peat as a raw material for the manufacture of various products [1]

\begin{tabular}{|c|c|c|c|c|}
\hline № & \multicolumn{2}{|c|}{ Type of products } & Lowland peat & $\begin{array}{l}\text { Horse and transitional } \\
\text { peat }\end{array}$ \\
\hline 1 & \multicolumn{2}{|l|}{ Fertilizer } & $\begin{array}{l}\mathrm{R}-\text { from } 15 \% \\
\mathrm{~A}^{\mathrm{c}}-\text { to } 35 \% \\
\mathrm{CaO}-\text { from } 10 \% \\
\mathrm{P}_{2} \mathrm{O}_{5}-\text { from } 1 \%\end{array}$ & $\begin{array}{l}\mathrm{R}-\text { from } 15 \% \\
\mathrm{~A}^{\mathrm{c}}-\text { from } 35 \%\end{array}$ \\
\hline 2 & \multicolumn{2}{|l|}{ Fuel } & $\begin{array}{l}\mathrm{R}-10 \% \text { and above } \\
\mathrm{A}^{\mathrm{c}}-\text { to } 35 \%\end{array}$ & $\begin{array}{l}\mathrm{R}-\text { from } 20 \% \\
\mathrm{~A}^{\mathrm{c}}-\text { to } 23 \%\end{array}$ \\
\hline 3 & \multicolumn{2}{|c|}{ Mountain wax } & \multicolumn{2}{|c|}{$\begin{array}{l}\text { All types of peat } \\
\text { Ac- to } 10 \%, \mathrm{R}-\text { from } 30 \% \text {, the main criteria } \\
\text { are the content of gasoline bitumen }-5 \%\end{array}$} \\
\hline 4 & \multicolumn{2}{|l|}{ Yeast } & - & $\begin{array}{l}\mathrm{R}-\text { from } 35 \% \\
\mathrm{~A}^{\mathrm{c}}-\text { to } 6 \%\end{array}$ \\
\hline 5 & \multicolumn{2}{|c|}{ Activated carbon } & - & $\begin{array}{l}\mathrm{R}-\text { from } 35 \% \\
\mathrm{~A}^{\mathrm{c}}-\text { to } 6 \%\end{array}$ \\
\hline 6 & Litter & 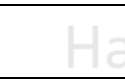 & \multicolumn{2}{|c|}{$\begin{array}{l}\text { All types of peat } \\
\mathrm{R} \text { - from } 15 \%-20 \%, \mathrm{~A}^{\mathrm{c}}-\text { to } 15 \% \odot \mathrm{CWT}\end{array}$} \\
\hline 7 & $\begin{array}{l}\text { Pots and } \\
\text { material }\end{array}$ & packing & \multicolumn{2}{|c|}{$\begin{array}{l}\text { All types of peat } \\
\mathrm{R}-\text { from } 10 \% \text { to } 25 \%, \mathrm{~A}^{\mathrm{c}} \text { - to } 15 \%\end{array}$} \\
\hline
\end{tabular}

Unfortunately, in the presence of such diverse peat raw materials, over $80 \%$ of Ukraine's peat, regardless of its properties, is burned, while in the world more than $80 \%$ of peat is used in agriculture as a source of humus (Fig. 4) [1].

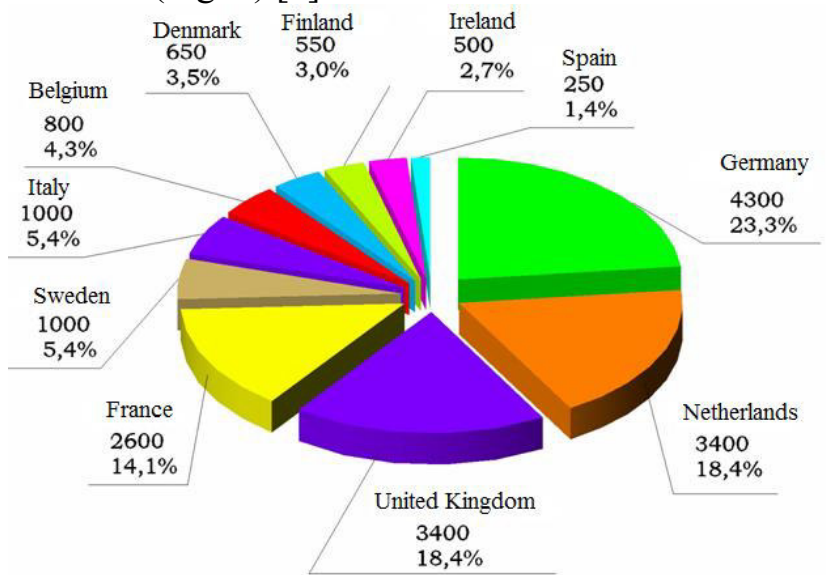

Fig. 4. Consumption of agricultural peat in Western Europe (thousand $\mathrm{m}^{3}$ ).

A total of $18,450,000 \mathrm{~m}^{3}$ 
Peat is a complex polydisperse multicomponent system; its physical properties depend on the properties of individual parts, the relationships between them, and the degree of decomposition or dispersion of the solid part [10]. Weakly decomposed peat is an excellent filtering material and highly dispersed is used as an antifiltration material. Peat absorbs and retains significant amounts of moisture, ammonia, cations (especially heavy metals).The filtration rate of peat varies within several orders of magnitude. Due to the variety of peat-forming plants and a wide range of peat accumulation conditions, the composition and properties of peat vary widely.

\section{Conclusions}

Areas of peat use are extremely diverse. The structure of peat resources, types of deposits and types of peat make them promising to use for different directions.

The future of intensive technologies for the use of peat in horticulture, horticulture, floriculture, balneology, production of peat carpets, plant and animal growth stimulants [2], rust converters, dyes, adsorbents for various purposes.

Analyzing the directions of peat use in the world, it is recommended that Ukraine pay attention to the introduction and use of alternative areas of peat.

\section{References}

1. Moshynskyi, V.S.Solvar, L.M., Semeniuk, V.V., Kucheruk, M.O. (2018). Technology of production and processing of peat at enterprises of the Rivneregion. Petroșani, Romania: Monograph: «Resource-saving technologies of rawmaterial base development in mineral mining and processing». UNIVERSITAS Publishing. P. 34-52. Retrieved from http://ep3.nuwm.edu.ua/18346/1/2\%20Moshynskyi\%20VS\%20\%281\%29.pdf

2. Bodnaryuk, T.S. (2008). Use of peat and peat deposits. Part 1. Rivne. 174 P.

3. Saranchuk, V.I., Ilyashov, M.O., Oshovsky, V.V., Biletsky, V.S. (2008). Fundamentals of chemistry and physics of combustible minerals. Part II . Donetsk. Oriental Publishing House. 640 P. Retrieved from https:/uchebnik-online.net/book/769osnovi-ximiyi-i-fiziki-goryuchix-kopalin-chastina-ii-posibnik-saranchuk-vi-ilyashov-mooshovskij-vv-bileckij-vs/ 6-8-torf-i-vugillya.html

4. Semenyuk, V.V., Kucheruk, M.O. (2020). Environmental justifications for the use of peat. Kazakhstan, Karaganda: International scientific-practical on-line conference "Integration of science, education and production - the basis for the implementation of the Plan of the Nation" (Sagin readings №12). KarSTU.P. 780-783.

5. Kucheruk, M., Strikha, V., Kirichik, I. (2017). Ecological prospects for the use of peat carpets in the development of peat deposits. Kryvyi Rih: II International Scientific and Technical Internet Conference "Innovative Development of the Mining Industry". P. 53. 
6. Vozniuk, S.T.,Moshinsky, V.S.andother (2017). Peatland resource of the NorthWestern region of Ukraine. NUVGP, Rivne.91 P.

7. Malanchuk, Z.R., Gavrish, V.S., Strikha, V.A., Kirichik, I. M. (2013). Technologies of open pit mining. NUVGP, Rivne. P. 255-277.

8. Inshekov, E. M., Chernyushok, L. M.(2012). Peat as an alternative source for thermal energy, on the example of the paper industry. Kyiv: Sustainable energy development. Technical University of Ukraine "Kyiv Polytechnic Institute named after Igor Sikorsky". P. 240-246. Retrieved from http://en.iee.kpi.ua/files/2012/240-246.pdf

9. Curly, V. P. (2003). Phytomelioration: textbook. Lviv: Svit. 540P.

10. Gray M. Peat resources of Ukraine: current state, prospect of use. Economic and social geography. Scientific Notes № 1. pp. 88-85, (2012).

https://doi.org/10.31713/m1005

\section{MONITORING OF THE BENCHES AND SIDES STABILITY OF THE QUARRIES}

Nizametdinov F.K.

Karaganda Technical University, Professor, Doctor of Technical Sciences, Professor, Department of Mine Surveying and Geodesy, Kazakhstan

Ozhigin S.G.

Karaganda Technical University, Professor, Doctor of Technical Sciences, Vice-rector on scientific work, Kazakhstan

Nizametdinov N.F.

Karaganda Technical University, Ph.D., Candidate of Technical Sciences, Senior Lecturer, Department of Mine Surveying and

Geodesy, Kazakhstan

\section{Oralbay A.O.}

Karaganda Technical University, Doctoral student, Department of Development of mineral deposits, Kazakhstan

Abstract. The increase in the volume of opencast mining is facing the main problem of ensuring the stability of the open pit slopes on the planned contour. To achieve this goal, required reliable geomechanical support of the parameters of the slopes of quarry benches and sides, then placing them on the planned contour using special technological schemes of the slopes and constant instrumental monitoring of their condition in an automated mode. The main emphasis in the work has been given to the method of instrumental monitoring of the quarry's arrays state using modern instruments with the analysis of their measurement's accuracy. The approved instrumental methods of monitoring at the open-pit mines of Kazakhstan are presented. 